Marquette University

e-Publications@Marquette

Education Faculty Research and Publications

Education, College of

$7-1-2004$

Neuropsychological Functioning of Homeless Men

Cindy L. Solliday-McRoy

Marquette University

Todd Campbell

Marquette University, todd.campbell@marquette.edu

Timothy P. Melchert

Marquette University, timothy.melchert@marquette.edu

Terrence Young

Marquette University, terrence.young@marquette.edu

Ron A. Cisler

University of Wisconsin - Milwaukee

Accepted version. The Journal of Nervous and Mental Disease, Vol. 192, No. 7 (July 2004): 471-478. DOI. This is a non-final version of an article published in final form in The Journal of Nervous and Mental Disease, Volume 192, 2004. 


\title{
Neuropsychological Functioning of Homeless Men
}

\author{
Cindy Solliday-McRoy* \\ Department of Counseling and Educational Psychology, \\ Marquette University \\ Milwaukee, WI \\ Todd C. Campbell* \\ Department of Counseling and Educational Psychology, \\ Marquette University \\ Milwaukee, WI \\ Timothy P. Melchert* \\ Department of Counseling and Educational Psychology, \\ Marquette University \\ Milwaukee, WI \\ Terence J. Young* \\ Department of Counseling and Educational Psychology, \\ Marquette University \\ Milwaukee, WI \\ Ron A. Cislert \\ Department of Health Sciences, \\ University of Wisconsin-Milwaukee and \\ Department of Population Health Sciences, \\ University of Wisconsin Medical School \\ Milwaukee, WI
}


NOT THE PUBLISHED VERSION; this is the author's final, peer-reviewed manuscript. The published version may be accessed by following the link in the citation at the bottom of the page.

Abstract: Numerous biological and psychological factors associated with impaired neurological functioning have been identified as common among the homeless, but there has been relatively little systematic examination of the cognitive functioning of homeless people. This study explored the neuropsychological functioning of 90 homeless men. There was great variability in their test scores, but the presence of possible cognitive impairment was detected in $80 \%$ of the sample. Average general intellectual functioning and reading abilities were found to be relatively low, and the incidence of impairments in reading, new verbal learning, memory, and attention and concentration was high. These findings suggest that the homeless men in this study had considerable assessment and treatment needs that were not being met by most of the health and social services offered to them.

Homelessness has always been prevalent in the United States. During the colonial period, large numbers of impoverished homeless people were treated in a variety of ways, ranging from being given small support payments to being forcibly transported to jurisdictional boundaries and urged to leave. This pattern continued through the emergence of skid rows in the late 19th century and into the Great Depression, when it appears that more money was spent in New York on "Greyhound relief" (bus tickets to bordering states) than on direct benefits to the homeless. The male laborers who lived in skid row provided a major source of labor as the United States industrialized during that period, but the demand for unskilled labor declined rapidly as technology advanced during the Depression and the 1940s. Since then, the shrinking availability of low-cost housing, the deinstitutionalization of the chronically mentally ill, and reduced income supports have affected the size and composition of the homeless population. The homeless have become more heterogeneous, with increasing numbers of women, minorities, and younger people, and an exponential increase in the number of families (Glasser and Bridgman, 1999; Helvie and Kunstmann, 1999).

The homeless have received increased media and research attention as they have become more numerous and visible in recent decades. Because of definitional and practical problems, however, accurate estimates of the number of homeless Americans are not available. Although people living in shelters or on the streets are normally considered homeless, there is much less agreement

Journal of Nervous and Mental Diseases, Vol. 192, No. 7 (July 2004): pg. 471-478. Publisher Link. This article is (C) Lippincott Williams \& Wilkins, Inc. and permission has been granted for this version to appear in e-

Publications@Marquette. Lippincott Williams \& Wilkins, Inc. does not grant permission for this article to be further copied/distributed or hosted elsewhere without the express permission from Lippincott Williams \& Wilkins, Inc.. 
regarding those living in other precarious circumstances such as in abandoned buildings, relatives' homes, or lodging paid for on a daily or weekly basis (Burt, 1996). It is also very difficult to enumerate people who do not have fixed addresses. Consequently, estimates of the number of homeless people in America vary widely. A widely cited estimate finds that more than 750,000 Americans were homeless on any given night in 2001, and more than 3 million people experienced homelessness during that year (National Law Center on Homelessness and Poverty, 2002). Helvie and Kunstmann (1999) estimated that 13.5 million Americans have been homeless at some point during their lifetime, and 5.7 million were homeless during the previous 5 years.

\section{Biopsychosocial Causes of Homelessness}

This brief overview suggests that the causes of homelessness are complex, and it is clear that the cause of homelessness for one person or family is frequently not a causal agent for others. A great deal is known about medical, psychological, and socioeconomic factors associated with homelessness, but the neuropsychological functioning of homeless people has received relatively little attention. It does appear, however, that although any one of these factors alone can trigger homelessness, it is a combination of factors that leads to homelessness in the majority of cases.

There is a relatively strong relationship between homelessness and various indicators of physical health, and the homeless have substantially higher rates of morbidity and mortality than the general population (Helvie and Kunstmann, 1999). Studies have found that $30 \%$ to $40 \%$ of the homeless suffer from chronic health problems, compared with $18 \%$ to $21 \%$ of the general population (Wright, 1987). These problems are often related to 1) lifestyle factors such as drug, alcohol, and tobacco use, poor nutrition, and lack of proper hygiene; 2) environmental factors such as exposure to extreme temperatures, crowded shelter conditions, and unsanitary living conditions; 3) susceptibility to victimization and violence; and 4) inadequate health care (Solomon and Jackson-Jobe, 1992). Specific health problems commonly found in this population include diabetes, hypertension, heart disease, malnutrition, human immunodeficiency virus, and traumatic brain injuries (TBIs; Helvie and Kunstmann, 1999). 
Psychological disorders are believed to be among the most significant causes of, or at least important risk factors for, homelessness. Studies consistently find that serious mental illness is several times more prevalent among the homeless than among the general population (Fischer and Breakey, 1991), and schizophrenia appears to be approximately 10 times more common (Folsom and Jeste, 2002). Several studies have found prevalence rates of $10 \%$ to $13 \%$ for schizophrenia, $21 \%$ to $29 \%$ for mood disorders, and $14 \%$ to $20 \%$ for antisocial personality disorder (Breakey et al., 1989).

After an extensive review of the research, Fischer and Breakey (1991) concluded that alcoholism was the most pervasive health problem among the homeless in the United States. The prevalence of alcohol abuse has been estimated to be as high as $68 \%$ among homeless men and 30\% among homeless women (Glasser and Bridgman, 1999). Homeless substance abusers have also been shown to have high rates of co-occurring mental disorders. For example, Koegel and Burnam $(1987,1988)$ found that nearly $70 \%$ of their homeless respondents with a lifetime diagnosis of substance abuse or dependence also had at least one additional psychological diagnosis: one third had a major affective disorder, and nearly $15 \%$ had schizophrenia.

Social factors also play an important role in homelessness. Certainly unemployment, poverty, and lack of affordable housing contribute to homelessness for many people-indeed, the working poor constitute a significant segment of the homeless population (US Department of Labor Bureau of Labor Statistics, 2003). Social policy changes and welfare reforms have led to sharp decreases in funding for various social programs that serve underprivileged and uninsured populations. There also appears to have been a breakdown of traditional family support so that people who suffer unemployment and financial hardship are less likely to be cared for by extended family members (Helvie and Kunstmann, 1999). In addition, one of the consequences of the women's rights movement appears to have been less acceptance of domestic violence, and some women are now more willing to leave abusive home situations even if it means that they, 
and often their children as well, will have to become homeless (Glasser and Bridgman, 1999).

\section{Neuropsychological Functioning of Homeless People}

There has been extensive research on substance abuse and mental illness among the homeless, but relatively little examination of the neuropsychological status of these people. There are signs, however, of significant problems in this area. Perhaps the first study to examine these issues found that $16 \%$ of a sample of skid row inhabitants exhibited evidence of Korsakoff psychosis, Wernicke disease, marked memory loss, epilepsy, and staggering gait (Olin, 1966). Tests of the general intelligence of various types of homeless samples have also usually found mean IQ scores below 85 (Cotman and Sandman, 1997; Seidman et al., 1997, 2003).

Studies using a variety of methodologies have found that between $3 \%$ and $80 \%$ of various homeless samples show signs of cognitive impairment (e.g., Douyon et al., 1998; Gonzalez et al., 2001; Menendez et al., 1995; Seidman et al., 1997). Many homeless people have demonstrated impairment in their ability to organize, integrate, and execute complex goal-directed behaviors, which can affect their ability to interact effectively with service providers and benefit from traditional psychosocial interventions and educational and vocational programming (US Federal Task Force on Homelessness and Severe Mental Illness, 1992).

Although neuropsychological assessment and treatment of the homeless tend to be inadequate or altogether lacking, neuropsychological assessments that focus on both the strengths and deficits of homeless people may be necessary if optimal treatment strategies are to be developed (Silver and Felix, 1999). Many researchers agree that the primary causes of homelessness may be unemployment, poverty, lack of affordable housing, and lack of community-based services, but also that neuropsychological dysfunction, whatever its cause, may increase certain people's risk for both becoming and remaining homeless.

Journal of Nervous and Mental Diseases, Vol. 192, No. 7 (July 2004): pg. 471-478. Publisher Link. This article is (C) Lippincott Williams \& Wilkins, Inc. and permission has been granted for this version to appear in e-

Publications@Marquette. Lippincott Williams \& Wilkins, Inc. does not grant permission for this article to be further copied/distributed or hosted elsewhere without the express permission from Lippincott Williams \& Wilkins, Inc.. 
To gain a better understanding of these issues, we administered a brief, comprehensive neuropsychological battery to a sample of homeless men in a large shelter in our city. The staff at the shelter has long had concerns about some of the men's cognitive abilities, but a literature review found no comprehensive data regarding the neuropsychological functioning of homeless men that could be used to inform the intake and assessment procedures and the psychoeducational and supportive programming that would be most helpful to these people.

\section{Methods}

\section{Participants}

A total of 90 homeless men living in a large shelter in Milwaukee, Wisconsin, participated in this study. Their mean age was 40.96 years (SD, 9.06; range, 20 to 63 ). A large majority ( $81 \%)$ were African American, $10 \%$ were white, $2 \%$ were Hispanic, and $7 \%$ were of other ethnic heritages. With regard to their highest level of education attained, 34\% had no degree of any kind, 31\% had a high school diploma, $21 \%$ had a General Equivalency Degree, $11 \%$ had an associate's degree, and $2 \%$ had a bachelor's degree. At the time of the study, $57 \%$ were unemployed, $11 \%$ were temporarily employed, $6 \%$ had a part-time position, $14 \%$ had a full-time position, and $12 \%$ were disabled. The participants reported that they had stayed in a shelter a mean number of 87.68 days during the previous 4 years (SD, 75.55; range, 5 to 320 days). The demographic characteristics of the sample are very similar to those of the entire population of people served by the shelter.

The participants' involvement in the study was completely voluntary and had no effect on shelter admissions, length of stay, or any other services that were offered. Their self-reported incidence of substance abuse or dependence (93\%), other mental health disorders $(50 \%)$, and TBIs (48\%) was high (Table 1 ). All participants agreed to abstain from the use of alcohol or drugs for at least 8 hours before the study tests were administered, but their reported length of abstinence from the use of substances was quite variable. 
NOT THE PUBLISHED VERSION; this is the author's final, peer-reviewed manuscript. The published version may be accessed by following the link in the citation at the bottom of the page.

\section{Instruments}

A questionnaire was used to gather demographic and biopsychosocial history information. The test battery that was used included the following instruments.

\section{Neurobehavioral Cognitive Status Examination}

The Neurobehavioral Cognitive Status Examination (Cognistat; Northern California Neurobehavioral Group, 1995) is a brief screening instrument designed to detect the presence of cognitive impairment in 10 areas. If the score on any one of the subtests falls below the average range of performance, the overall test result is considered a positive screen for impaired cognitive functioning. The Cognistat is reported to have moderately good to high sensitivity and specificity for detecting cognitive impairment and to be equally as effective or more effective than several other screening tests (e.g., Kazmark, 1997; van Gorp et al., 1999).

\section{Wechsler Abbreviated Scale of Intelligence}

The Wechsler Abbreviated Scale of Intelligence (WASI; Psychological Corp., 1999b) is a measure of general intellectual functioning composed of four subtests. The vocabulary, block design, similarities, and matrix reasoning subtests on the WASI yield verbal IQ (VIQ), performance IQ (PIQ), and full-scale IQ (FSIQ) scores that correlate $.88, .84$, and .92 with their corresponding scores on the Wechsler Adult Intelligence Scale-Third Edition (WAIS-III; Psychological Corp., 1997, 1999a). Reported reliability coefficients for these three scales range from .84 to .98 (Psychological Corp., 1999b).

\section{Digit Span Subtest of the Wechsler Adult Intelligence Scale- Third Edition}

The digit span subtest consists of two parts. The examinee listens to a series of digits presented orally and then repeats the digits in the identical sequence for digits forward and in reverse order for digits backward. Digits forward tends to examine the efficiency of attentional processing, whereas digits backward requires the use of 
memory strategies and the ability to track multiple stimuli simultaneously (Lezak, 1995). Split-half reliability for this subtest was found to be .90 (Psychological Corp., 1999a).

\section{Rey Auditory Verbal Learning Test}

The Rey Auditory Verbal Learning Test (RAVLT; Spreen and Strauss, 1998) is a measure of new verbal learning abilities, susceptibility to interference, immediate and delayed memory, and recognition memory. The most common version of this test was used in this study and consists of 15 nouns read aloud for five trials, each followed by a free recall test. This is followed by a free recall test of an interference list of 15 words, followed by the free recall of the original list. After a 30-minute delay, examinees recall words from the original list followed by a test of their ability to recognize words from that list. Spreen and Strauss (1998) reported that the RAVLT had moderate test-retest reliability and high sensitivity to neurological impairment, laterality of brain damage, and verbal memory deficits.

\section{Rey-Osterrieth Complex Figure Test}

The Rey-Osterrieth Complex Figure Test (RCFT; Osterrieth, 1944; Rey, 1941) measures a variety of nonverbal processes including cognitive processing speed, visuomotor and visual-perceptual integration skills, and visuospatial recall ability. The basic procedure involves copying a figure and then reproducing it from memory after 3 minutes (immediate recall) and after 30 minutes (delayed recall). Spreen and Strauss (1998) reported high interrater reliability and sensitivity for a number of neurocognitive disorders.

Letter-Word Identification and Passage Comprehension Subtests of the Woodcock Johnson Psychoeducational Battery-Revised: Tests of Achievement

The Standard Battery of the Woodcock Johnson Psychoeducational Battery-Revised: Tests of Achievement (WJ-R ACH; Woodcock and Johnson, 1990) consists of nine subtests, of which two were selected to measure reading abilities. Letter-word identification measures ability to identify letters and words, and passage 
NOT THE PUBLISHED VERSION; this is the author's final, peer-reviewed manuscript. The published version may be accessed by following the link in the citation at the bottom of the page.

comprehension measures skill in supplying an appropriate word to complete a short passage. The WJ-R ACH is considered a technically excellent instrument with reliability and validity coefficients greater than the mid .80s (Spreen and Strauss, 1998).

\section{Procedure}

When the participants arrived for their assessment sessions, they were reminded that their participation would not prejudice their shelter stay in any way and that all the assessment results would remain entirely confidential. Each participant was paid $\$ 10$. The tests were administered by professional psychology doctoral students who were supervised by two licensed psychologists.

\section{Results}

The large majority of the study sample (80\%) demonstrated performances on the Cognistat that suggested impaired cognitive functioning (i.e., their scores on at least one of the 10 subtests fell within the impaired range of performance). The subtest on which participants were most likely to score in the impaired range was memory (64\%; Table 2).

On average, the study participants demonstrated below average general intellectual abilities on the WASI. Their mean VIQ score was 83.73 (SD, 16.03), mean PIQ score was 87.07 (SD, 14.87), and mean FSIQ was 83.92 (SD, 15.24). Nearly half of the sample received VIQ (48\%), PIQ (39\%), and FSIQ (50\%) scores that fell below 85, which tends to indicate diminished capacities in a broad range of cognitive abilities (Lezak, 1995; Spreen and Strauss, 1998). Twenty percent also received FSIQ scores of 70 or below, the range generally required for a diagnosis of mental retardation. Specifically, 4\% obtained FSIQ scores in the high average range (110 to 119 ), $31 \%$ in the average range (90 to 109 ), $24 \%$ in the low average range (80 to 89 ), $20 \%$ in the borderline range ( 70 to 79 ), and $20 \%$ in the extremely low range $(\leq 69)$.

Twenty-eight percent of the participants received standard scores of less than 85 on the digit span subtest, suggesting the 
presence of possible attentional problems. The mean score was 94.68 (SD, 15.17), whereas the mean number of digits forward was 6.08 $(S D, 1.45)$ and the mean number of digits backward was 4.28 (SD, 1.28). Two percent scored in the very superior range, $6 \%$ in the superior range, $8 \%$ in the high average range, $40 \%$ in the average range, $32 \%$ in the low average range, $11 \%$ in the borderline range, and $1 \%$ in the extremely low range.

The results from the RAVLT (Table 3) suggested verbal learning and memory deficits in more than half the sample. Sixty percent received standard scores below 85 on trials I to V, $48 \%$ on the interference subtest, $52 \%$ on immediate recall, $53 \%$ on delayed recall, and $30 \%$ on the recognition task.

The RCFT results suggested major deficits in cognitive processing speeds, visuomotor and visual-perceptual integration skills, and visuospatial memory for nearly three quarters of the sample (Table 4). Seventy-two percent received standard scores below 85 on both immediate recall and delayed recall.

The average reading abilities demonstrated by the sample on the WJ-R ACH subtests were at the eighth and ninth grade levels. The mean grade equivalent score on letter-word identification was 9.29 $(\mathrm{SD}, 4.56) ; 14 \%$ scored at the third grade or lower, $9 \%$ at the fourth to fifth grade level, $28 \%$ at the sixth to eighth grade level, $28 \%$ at the ninth to 12 th grade level, and $21 \%$ at the 13 th to 16 th grade level. The mean passage comprehension grade equivalent score was 8.27 $(\mathrm{SD}, 4.52) ; 18 \%$ scored at the third grade level or lower, $13 \%$ at the fourth or fifth grade level, $27 \%$ at the sixth to eighth grade level, $23 \%$ at the ninth to 12 th grade level, and $16 \%$ at the 13 th to 16 th grade level.

Analyses of variance were computed for each of these measures between those who reported and did not report a history of TBI, substance abuse or dependence, and mental disorder. A surprising finding was that no statistically significant differences were found with any of these analyses. The reported length of loss of consciousness associated with a TBI was also not correlated with any of the neuropsychological test scores. Correlations between the test scores

Journal of Nervous and Mental Diseases, Vol. 192, No. 7 (July 2004): pg. 471-478. Publisher Link. This article is (C) Lippincott Williams \& Wilkins, Inc. and permission has been granted for this version to appear in e- 
and age, years of education, length of current abstinence from alcohol and drugs, length of loss of consciousness associated with TBI, and total number of days stayed in a shelter over the period of the past 4 years also revealed few significant findings. Not unexpectedly, years of education was correlated with scores on FSIQ $(r=.62 ; p<.001)$, digit span forward $(r=.39 ; p<.001)$, digit span backward $(r=.32 ; p<$ $.001)$, RAVLT trials I-V $(r=.43 ; p<.001)$, and the WJ-R letter-word $(r=.49 ; p<.001)$ and passage comprehension $(r=.48 ; p<.001)$ subtests. None of the other correlations, however, were statistically significant (at $p<.03$ ). Also not surprisingly, FSIQ was significantly correlated with nearly all of the other test scores (correlations ranged between .29 and .77).

\section{Discussion}

Recent studies examining neuropsychological functioning in the homeless population are finding major causes for concern. In this study, use of the Cognistat found a very high proportion of people $(80 \%)$ who showed signs of possible cognitive impairment, findings very similar to those of other recent studies of this population (e.g., Gonzalez et al., 2001; Seidman et al., 1997, 2003). The average level of general intellectual functioning of the sample also fell in the range suggestive of possible cognitive impairment $(<85)$-the mean FSIQ score was 83.73. Though there was significant variability in the IQ scores obtained by the participants, 20\% received FSIQ scores of below 70, the range used in the diagnosis of mental retardation (only $2 \%$ of the general population score in this range).

Generalized memory deficits were detected in more than half the sample. Deficits in new verbal learning abilities are probable in the $60 \%$ of the participants scoring below 85 on the RAVLT. Impairments in cognitive processing speeds, visuomotor and visual-perceptual integration skills, and verbal and nonverbal recall abilities were detected in nearly three quarters of the sample based on the RCFT results. Approximately one quarter to one third of the sample had reading abilities at or below the fifth grade level, and approximately one sixth scored at the third grade level or lower. 
A rather remarkable finding of this study was that none of the neuropsychological test scores were statistically associated with a reported history of TBI, mental disorder, or substance abuse and dependence. The IQ and other test scores were also not correlated with participants' reported number of days stayed in a shelter. Taken together with the very high proportion of participants who showed signs of neuropsychological problems, these results clearly suggest that the possibility of cognitive impairment should be considered when working with all people in this population. Although there is a possibility of cognitive impairment in this population, the large amount of variability in all of the study test scores must also be noted (e.g., the number of participants scoring at the third grade level or lower on the reading tests was similar to the number scoring at the college level). Education level was correlated with several of the test scores, but this finding was not unexpected-indeed, the correlation between FSIQ and education level found here (.62) was very similar to the .67 correlation found in the Wechsler Adult Intelligence Scale-Revised (WAIS-R) standardization sample (Reynolds et al., 1987).

It is also important to note that the cognitive deficits detected in this sample may not be reflective of permanent neurological damage. For instance, the below-average general intellectual functioning and poor reading abilities demonstrated by many of the participants may be more reflective of level of formal education than permanent deficits in cognitive abilities. Substance abuse or dependence was also reported by $93 \%$ of the participants, and this factor has consistently been associated with a variety of neuropsychological deficits (e.g., Fals-Stewart et al., 1994; Marshall, 1999). One half of the sample $(50 \%)$ also reported previous mental health diagnoses, with the majority for mood disorders (28\%). Appropriate mental health assessment and treatment may help alleviate the cognitive impairments associated with these disorders. Stable housing has also been associated with clinically modest improvements in the neuropsychological functioning of a sample of homeless people with severe and persistent mental illness (Seidman et al., 2003).

Improvement in cognitive functioning might be expected as a result of appropriate interventions with these people, but studies consistently find that neuropsychological deficits are moderately 
predictive of mental health treatment outcome, and people with greater impairment have the poorest prognosis for improvement (Allen et al., 1997). In fact, people with serious addictions, co-occurring mental health disorders, and cognitive impairment appear to have the poorest treatment outcomes of all (Fals-Stewart and Lucente, 1994).

Many homeless people seek treatment at social service agencies in crisis, with complex problems, chaotic lifestyles, and little social support. Their presenting problems can be so pressing that more subtle issues, such as mild or moderate cognitive problems, are often ignored. The results of this study suggest that many homeless people have significant or global cognitive impairments that will directly affect their ability to benefit from many of the services and treatment strategies currently offered to this population. Standard interventions such as motivational interviewing, relapse prevention, cognitive behavioral therapy, psychoeducation, or group and family therapy are likely to be ineffective if they are too cognitively demanding and inappropriately conceived for the abilities of these people. Instead, these people may respond best to behavior modification strategies that provide well-defined goals, repetition of material, concrete explanations, continual reinforcement of desired behaviors, and aids for memory enhancement. Cognitive rehabilitation, vocational training, and other structured skill learning procedures should also be considered for use with these people.

Substance abuse and dependency were certainly prevalent among the participants in this study, and this factor also needs to figure prominently in the programming offered to these people. Alcoholics Anonymous and other 12-step programs can be well suited to the needs of substance abusing people with mild to moderate cognitive impairments, and many homeless people with substance abuse problems lack a social support network for recovery, which these programs can provide (Fals-Stewart et al., 1994; Longabaugh et al., 1998). The study results also suggest that there may be a significant minority of homeless people with more serious cognitive impairments, particularly those with IQ scores below 70. Many literacy experts believe that adults with reading abilities similar to those demonstrated by almost one third of the men in this study (at or below the fifth grade level) lack a sufficient foundation of basic skills 
necessary for functioning adequately in society (National Institute for Literacy, 2000).

Future research should continue to examine these topics, because the implications of the results found here are substantial. Although other studies have found similar patterns of results, it must be emphasized that the generalizability of the present results is unknown. The effect of ethnicity, sex, and age also was not explored. Given the growing evidence supporting this pattern of results, however, an underdiagnosis and inappropriate treatment problem of crisis proportions may exist in this population. Further clarification of the size and nature of this problem could have a major effect on the allocation of funding and level of staff training needed for developing, implementing, and evaluating appropriate services for homeless people. Without more attention to these issues, homelessness will continue to persist as a pervasive social problem that creates a massive amount of preventable suffering.

\section{Conclusion}

Signs of cognitive impairment were found in $80 \%$ of the homeless men who participated in this study. There was great variability in the level of cognitive functioning of the sample, but it was also unrelated to factors such as a self-reported history of traumatic head injury, substance abuse and dependence, or length of shelter stay. These findings suggest that there may be a large underdiagnosis and inappropriate treatment problem of large proportions with regard to this population. Many of the services offered to this population need to be thoroughly restructured to meet their needs.

\section{Notes}

- *Department of Counseling and Educational Psychology, Marquette University, Milwaukee, WI; and tDepartment of Health Sciences, University of Wisconsin-Milwaukee and Department of Population Health Sciences, University of Wisconsin Medical School, Milwaukee, WI.

- $\quad$ Supported in part by a grant from the Center for Addictions and Behavioral Health Research, Milwaukee, WI. 
NOT THE PUBLISHED VERSION; this is the author's final, peer-reviewed manuscript. The published version may be accessed by following the link in the citation at the bottom of the page.

- Send reprint requests to Timothy P. Melchert, Department of Counseling and Educational Psychology, 146 Schroeder Complex, Marquette University, Milwaukee, WI 53201.

\section{References}

Allen D, Goldstein G, Seaton B (1997) Cognitive rehabilitation of chronic alcohol abusers. Neuropsychol Rev. 7:21-39.

Breakey W, Fischer P, Kramer M, Nestadt G, Romanoski A, Ross A, Royall R, Stine $O(1989)$ Health and mental health problems of homeless men and women in Baltimore. JAMA. 262:1352-1357.

Burt M (1996) Homelessness: Definitions and counts. In J Baumohl (Ed), Homeless in America (pp 15-23). Phoenix, AZ: Oryx Press.

Cotman A, Sandman C (1997) Cognitive deficits and their remediation in the homeless. J Cogn Rehabil. 15:16-23.

Douyon R, Guzman P, Romain G, Ireland S, Mendoza L, Lopen-Blanco M, Milanes $F$ (1998) Subtle neurological deficits and psychopathological findings in substance abusing homeless and non-homeless. $J$

Neuropsychiatry Clin Neurosci. 10:210-215.

Fals-Stewart W, Lucente S (1994) Effect of neurocognitive status and personality functioning on length of stay in residential substance abuse treatment: An integrative study. Psychol Addict Behav. 8:179-190.

Fals-Stewart W, Schafer J, Lucente S, Rustine T, Brown L (1994) Neurobehavioral consequences of prolonged alcohol and substance abuse: A review of findings and treatment implications. Clin Psychol Rev. 14:755-778.

Fischer P, Breakey W (1991) The epidemiology of alcohol, drug and mental disorder among homeless persons. Am Psychol. 46:1115-1118.

Folsom D, Jeste DF (2002) Schizophrenia in homeless persons: A systematic review of the literature. Acta Psychiatr Scand. 105:404-413.

Glasser I, Bridgman R (1999) Braving the Street: An Anthropology of Homelessness. New York: Berghahn Books.

Gonzalez EA, Dieter JN, Natale RA, Tanner SL (2001) Neuropsychological evaluation of higher functioning homeless persons: A comparison of an abbreviated test battery to the Mini-Mental State Exam. J Nerv Ment Dis. 189:176-181.

Helvie C, Kunstmann W (1999) Homelessness in the United States, Europe and Russia: A Comparative Perspective. Westport, CT: Bergin \& Garvey.

Kazmark P (1997) Operating characteristics of the neurobehavioral cognitive status exam using neuropsychological assessment as the criterion. Assessment. 4:1-8.

Journal of Nervous and Mental Diseases, Vol. 192, No. 7 (July 2004): pg. 471-478. Publisher Link. This article is (C) Lippincott Williams \& Wilkins, Inc. and permission has been granted for this version to appear in e-

Publications@Marquette. Lippincott Williams \& Wilkins, Inc. does not grant permission for this article to be further copied/distributed or hosted elsewhere without the express permission from Lippincott Williams \& Wilkins, Inc.. 
NOT THE PUBLISHED VERSION; this is the author's final, peer-reviewed manuscript. The published version may be

accessed by following the link in the citation at the bottom of the page.

Koegel P, Burnam M (1987) The Epidemiology of Alcohol Abuse and Dependence Among Homeless Individuals: Findings From the InnerCity of Los Angeles. Los Angeles: University of California Department of Psychiatry.

Koegel P, Burnam M (1988) Alcoholism among homeless adults in the innercity of Los Angeles. Arch Gen Psychiatry. 45:1011-1018.

Lezak M (1995) Neuropsychological Assessment. (3rd ed). New York: Oxford University Press.

Longabaugh R, Wirtz P, Zweben A, Stout R (1998) Network support for drinking, alcoholics anonymous and long-term matching effects. Addiction. 93:1313-1333.

Marshall J (1999) Neuropsychiatry in substance abuse. In F Ovsiew (Ed), Neuropsychiatry and Mental Health Services (pp 105-149).

Washington, DC: American Psychiatric Press.

Menendez G, de La Torre A, Rodriguez G, Medina C (1995) Homeless and psychiatric pathology. Anales Psiquiatr. 11:163-169.

National Law Center on Homelessness and Poverty (2002) Homelessness and Poverty in America. Washington, DC: National Law Center on Homelessness and Poverty.

National Institute for Literacy (2001) Frequently Asked Questions. Available at: http://www.nifl.gove/nifl/faqs.html.

Northern California Neurobehavioral Group (1995) Manual for Cognistat. Fairfax, CA: Northern California Neurobehavioral Group.

Olin J (1966) "Skid row" syndrome: A medical profile of the chronic drunkenness offender. Can Med Assoc J. 95:205-214.

Osterrieth P (1944) Le test de copie d'une figure complex: Contribution a l'etude de la perception et de la memoire. Arch Psychol. 30:286-356.

Psychological Corp. (1997) Wechsler Adult Intelligence Scale-Third Edition. San Antonio, TX: Harcourt Brace.

Psychological Corporation (1999a) WAIS-III WMS-III Technical Manual. San Antonio, TX: Harcourt Brace.

Psychological Corporation (1999b) Wechsler Abbreviated Scale of Intelligence Manual. San Antonio, TX: Harcourt Brace.

Rey A (1941) L'examen psychologique dans les cas d'encephalopathie traumatique. Arch Psychol. 28:286 -340.

Reynolds CR, Chastain RL, Kaufman AS, McLean JE (1987) Demographic characteristics and IQ among adults: Analysis of the WAIS-R standardization sample as a function of the stratification variables. $J$ School Psychol. 25:323-342.

Seidman L, Caplan B, Tolomiczenko G, Turner W, Penk W, Schutt R, Goldfinger S (1997) Neuropsychological function in homeless mentally ill individuals. J Nerv Ment Dis. 186:3-12.

Journal of Nervous and Mental Diseases, Vol. 192, No. 7 (July 2004): pg. 471-478. Publisher Link. This article is (C) Lippincott Williams \& Wilkins, Inc. and permission has been granted for this version to appear in e-

Publications@Marquette. Lippincott Williams \& Wilkins, Inc. does not grant permission for this article to be further copied/distributed or hosted elsewhere without the express permission from Lippincott Williams \& Wilkins, Inc. 
NOT THE PUBLISHED VERSION; this is the author's final, peer-reviewed manuscript. The published version may be accessed by following the link in the citation at the bottom of the page.

Seidman L, Schutt R, Caplan B, Tolomiczenko G, Turner W, Goldfinger S (2003) The effect of housing interventions on neuropsychological functioning among homeless persons with mental illness. Psychiatr Serv. 54:905-908.

Silver J, Felix A (1999) Neuropsychiatry and the homeless. In F Ovsiew (Ed), Neuropsychiatry and Mental Health Services (pp 319 -333). Washington, DC: American Psychiatric Press.

Solomon C, Jackson-Jobe P (1992) Helping Homeless People: Unique Challenges and Solutions. Alexandria, VA: American Association for Counseling and Development.

Spreen O, Strauss E (1998) A Compendium of Neuropsychological Tests: Administration, Norms and Commentary (2nd ed). New York: Oxford University Press.

US Federal Task Force on Homelessness and Severe Mental Illness (1992) Outcasts on Mainstreet. Washington, DC: Department of Health and Human Services.

US Department of Labor Bureau of Labor Statistics (2003) A Profile of the Working Poor, 2001 (report 968). Washington, DC: US Department of Labor Bureau of Labor Statistics.

van Gorp W, Wilfred G, Marcotte T, Sultzer D, Hinkin C, Mahler M, Cummings J (1999) Screening for dementia: Comparison of three commonly used instruments. J Clin Exp Neuropsychol. 12:29-38.

Woodcock R, Johnson M (1990) Woodcock-Johnson Psycho-Educational Battery-Revised. Itasca, IL: Riverside Publishing.

Wright J (1987) Selected Topics in the Health Care of America's Homeless: Special Report to the Institute of Medicine. Washington, DC: Institute of Medicine.

Journal of Nervous and Mental Diseases, Vol. 192, No. 7 (July 2004): pg. 471-478. Publisher Link. This article is (C) Lippincott Williams \& Wilkins, Inc. and permission has been granted for this version to appear in e-

Publications@Marquette. Lippincott Williams \& Wilkins, Inc. does not grant permission for this article to be further copied/distributed or hosted elsewhere without the express permission from Lippincott Williams \& Wilkins, Inc. 
NOT THE PUBLISHED VERSION; this is the author's final, peer-reviewed manuscript. The published version may be accessed by following the link in the citation at the bottom of the page.

\section{Appendix}

\section{Table 1}

Self-reported health history

\begin{tabular}{|c|c|c|}
\hline Variable & $N$ & Percent \\
\hline \multicolumn{3}{|l|}{ Had received treatment for mental health } \\
\hline Yes & 45 & 50 \\
\hline No & 45 & 50 \\
\hline \multicolumn{3}{|l|}{ Type of mental health treatment received } \\
\hline $\begin{array}{l}\text { No reported history of mental health } \\
\text { treatment }\end{array}$ & 45 & 50 \\
\hline $\begin{array}{l}\text { Disorders usually diagnosed in infancy, } \\
\text { childhood, or Adolescence }\end{array}$ & 1 & 1 \\
\hline Substance-related disorders & 6 & 7 \\
\hline Schizophrenia/other psychotic disorders & 7 & 8 \\
\hline Mood disorders & 25 & 28 \\
\hline Anxiety disorders & 4 & 4 \\
\hline Other & 2 & 2 \\
\hline \multicolumn{3}{|l|}{ History of TBI involving loss of consciousness } \\
\hline Yes & 43 & 48 \\
\hline No & 47 & 52 \\
\hline \multicolumn{3}{|l|}{ Length of TBI loss of consciousness } \\
\hline No TBI history & 47 & 52 \\
\hline$>24 \mathrm{~h}$ & 10 & 11 \\
\hline$\leq 24 \mathrm{~h},>20 \mathrm{~min}$ & 6 & 7 \\
\hline$\leq 20 \mathrm{~min}$ & 27 & 30 \\
\hline \multicolumn{3}{|l|}{ Substance abuse/dependence history } \\
\hline Yes & 84 & 93 \\
\hline No & 6 & 7 \\
\hline \multicolumn{3}{|l|}{ Type of substance abuse/dependence } \\
\hline No substance abuse/dependence & 6 & 7 \\
\hline Polysubstance & 67 & 74 \\
\hline Cocaine & 10 & 11 \\
\hline Alcohol & 6 & 7 \\
\hline Other & 1 & 1 \\
\hline \multicolumn{3}{|l|}{ Length of current abstinence } \\
\hline $8-24 \mathrm{~h}$ & 2 & 2 \\
\hline $1-2 d$ & 10 & 7 \\
\hline $3 \mathrm{~d}-1 \mathrm{wk}$ & 14 & 15 \\
\hline$>1 \mathrm{wk}$ and $<1 \mathrm{mo}$ & 16 & 18 \\
\hline $1-2 \mathrm{mo}$ & 16 & 18 \\
\hline $3-6 \mathrm{mo}$ & 10 & 11 \\
\hline $7-11 \mathrm{mo}$ & 4 & 4 \\
\hline $1 \mathrm{yr}$ & 10 & 11 \\
\hline $2+y$ & 8 & 9 \\
\hline
\end{tabular}

Journal of Nervous and Mental Diseases, Vol. 192, No. 7 (July 2004): pg. 471-478. Publisher Link. This article is (C) Lippincott Williams \& Wilkins, Inc. and permission has been granted for this version to appear in e- 
NOT THE PUBLISHED VERSION; this is the author's final, peer-reviewed manuscript. The published version may be accessed by following the link in the citation at the bottom of the page.

\section{Table 2}

\section{Cognistat test results ${ }^{a}$}

\begin{tabular}{|l|c|c|c|c|c|c|}
\hline \multicolumn{1}{|c|}{ Subtest } & Mean & SD & $\begin{array}{c}\text { Severe } \\
\text { impairment }\end{array}$ & $\begin{array}{c}\text { Moderate } \\
\text { impairment }\end{array}$ & $\begin{array}{c}\text { Mild } \\
\text { impairment }\end{array}$ & $\begin{array}{c}\text { Average } \\
\text { performance }\end{array}$ \\
\hline Orientation & 11.87 & 0.77 & 0 & 1 & 1 & 98 \\
\hline Attention & 6.56 & 1.57 & 2 & 10 & 9 & 79 \\
\hline Comprehension & 5.62 & 0.66 & 1 & 0 & 3 & 96 \\
\hline Repetition & 11.62 & 1.14 & 2 & 1 & 3 & 93 \\
\hline Naming & 7.50 & 0.67 & 0 & 0 & 6 & 94 \\
\hline Constructions & 4.56 & 1.48 & 3 & 8 & 9 & 80 \\
\hline Memory & 7.73 & 3.10 & 22 & 24 & 18 & 36 \\
\hline Calculations & 3.11 & 1.01 & 2 & 2 & 26 & 70 \\
\hline Similarities & 5.80 & 2.06 & 8 & 3 & 14 & 74 \\
\hline Judgment & 4.97 & 1.13 & 1 & 1 & 9 & 89 \\
\hline
\end{tabular}

"Mean and SD scores are reported for the subtest raw scores, and percentages are reported for the various levels of performance.

\section{Table 3}

RAVLT test results ${ }^{a}$

\begin{tabular}{|l|c|c|c|c|c|c|c|}
\hline \multicolumn{1}{|c|}{ Subtest } & $\begin{array}{c}\text { Extremely } \\
\text { low }\end{array}$ & Borderline & $\begin{array}{c}\text { Low } \\
\text { average }\end{array}$ & Average & $\begin{array}{c}\text { High } \\
\text { Average }\end{array}$ & Superior & $\begin{array}{c}\text { Very } \\
\text { superior }\end{array}$ \\
\hline Trials 1-V (mean, 77.79; SD, 20.39) & 33 & 16 & 20 & 26 & 4 & 1 & 0 \\
\hline $\begin{array}{l}\text { Interference (mean, 85.62; S0. } \\
\text { 13.05) }\end{array}$ & 16 & 11 & 33 & 38 & 2 & 0 & 0 \\
\hline $\begin{array}{l}\text { Immediate tecall (mean, 82.07; SD, } \\
18.99 \text { ) }\end{array}$ & 29 & 13 & 17 & 34 & 6 & 1 & 0 \\
\hline $\begin{array}{l}\text { Delayed recall (mean, 82.01; SD, } \\
20.32 \text { ) }\end{array}$ & 29 & 20 & 13 & 28 & 8 & 2 & 0 \\
\hline $\begin{array}{l}\text { Rocognition task (mean, 88.30; SD, } \\
25.81 \text { ) }\end{array}$ & 21 & 4 & 12 & 24 & 38 & 0 & 0 \\
\hline
\end{tabular}

"Reguts are reported in percertagas for each of the vanous levels of pertormance. The standard scoreg cortesponding to the performance layels are as folows. extremely low 569 , borderine $=70-79$, low sverage $=60-89$, sverege $* 80-109$, high average $=110-119$, supenor $=120-129$, and very superior $\geq 190$.

\section{Table 4}

\section{RCFT test results ${ }^{a}$}

\begin{tabular}{|c|c|c|c|c|c|c|c|}
\hline Subtest & $\begin{array}{l}\text { Extremely } \\
\text { low }\end{array}$ & Borderline & $\begin{array}{l}\text { Low } \\
\text { average }\end{array}$ & Average & $\begin{array}{l}\text { High } \\
\text { average }\end{array}$ & Superior & $\begin{array}{l}\text { Very } \\
\text { superior }\end{array}$ \\
\hline Copy time (mean, $252.90 ;$ SD, 107.57 ) & 8 & 17 & 9 & 67 & 0 & 0 & 0 \\
\hline Copy accuracy (mean, 31,$97 ;$ SD, 19.82 ) & 36 & 13 & 2 & 49 & O & 0 & 0 \\
\hline $\begin{array}{l}\text { Immediate recall accurscy (mean, } 74.89 ; \\
\mathrm{SD}, 20.15 \text { ) }\end{array}$ & 46 & 18 & 14 & 16 & 3 & 2 & 1 \\
\hline $\begin{array}{l}\text { Delayed recall accuracy (mean, } 73.70 \text {; } \\
\text { SD, 20.46) }\end{array}$ & 49 & 19 & 8 & 17 & 7 & 1 & 0 \\
\hline
\end{tabular}

"Results are reported in percentages for each of the various levels of performance.

Journal of Nervous and Mental Diseases, Vol. 192, No. 7 (July 2004): pg. 471-478. Publisher Link. This article is (C) Lippincott Williams \& Wilkins, Inc. and permission has been granted for this version to appear in e-

Publications@Marquette. Lippincott Williams \& Wilkins, Inc. does not grant permission for this article to be further copied/distributed or hosted elsewhere without the express permission from Lippincott Williams \& Wilkins, Inc.. 